8 Kottkamp H, Hindricks G, Willems S, Chen X, Reinhardt L, Haverkamp W, et al. An anatomically and electrogram-guided stepwise approach for

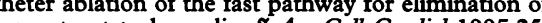
974-81.

9 Langberg JJ, Leon A, Borganelli M, Kalbfleisch SJ, El-Atassi R, Calkins H, et al. A randomised prospective comparison of anterior and posterior approaches to radiofrequency catheter ablation of atrioventricular nodal tachycardia. Circulation 1993;87:1551-6.

10 Hindrincks G. The Multicentre European Radiofrequency Survey (MERFS): complications of radiofrequency catheter ablation of arrhythmias. Eur Heart $₹$ 1993;14:1644-53.
11 Ho SY, McComb JM, Scott CD, Anderson RH. Morphology of the cardiac conduction system in patients with electrophysiologically proven dual conduction system in patients with electrophysiologically proven dua Garratt CJ, Skehan JD, Payne GE, Stafford PJ. Effect of sequential Garratt CJ, Skehan JD, Payne GE, Stafford PJ. Effect of sequential radiofrequency ablation lesions at fast and slow AV nodal pathway positions in pacients with paroxysmal atrial fibrillation. Heart 1996;75:502-8.

13 Garratt CJ, Anderson RH. Targeting the "upper-turn-around" in atrioventricular nodal reentrant tachycardia. Int f Cardiol 1995;51:283-4.

14 Manolis AS, Wang PJ, Estes NA. Radiofrequency ablation of slow pathway in patients with atrioventricular nodal reentrant tachycardia. Do arrhythmia recurrences correlate with persistent slow pathway conduction or site of successful ablation? Circulation 1994;90:2815-19.

\title{
STAMPS IN CARDIOLOGY
}

\section{Jean Nicolas Corvisart (1755-1821)}

The stamp was issued by France on 12 December 1964 as part of the Red Cross Fund set. The surcharge of +10 centimes is the contribution to the Red Cross Organisation. France first issued stamps to raise funds for the Red Cross Organisation in 1914 and has issued a set of Red Cross stamps each year since 1950. Illustrated here is the First Day Cover postmarked 12 December 1964 and cancelled with the Red Cross logo. The cover features the portrait of Corvisart, highlights the heart and direction of blood flow, and is inscribed vertically with the title of his book published in 1806.

The Red Cross is one of the organisations most frequently benefiting from charitable funds raised by the purchase of postage stamps. The First World War Red Cross stamps were overprints of the stamps in regular use at the time, giving the advantage of rapid production and fundraising rather than having to delay while a specific Red Cross stamp was designed, printed, and distributed. In these early stamps the time and place of overprinting varied because many were produced locally: the variable position and type of the Red Cross overprint identifies their origins.

In 1795 Jean Nicolas Corvisart became the first professor of medicine at the Charite Hospital in Paris. His Essai sur les maladies et les lésions organiques du coeur et des gros vaisseaux, published in 1806, was one of the first books on this subject and was translated into English in the United States in 1812. In it he describes a man of 48 shown at necropsy to have severe calcific aortic stenosis, in whom he diagnosed "constriction of the aortic orifice" from the "undulating and tremulous" character of the pulse. This was preLaennec, but he recognised in some cases of valve disease there was a "peculiar rushing like water" sensation which could be felt over the heart, caused, he said, by blood passing through a narrowed valve.

Corvisart became impressed by the value of the new diagnostic method of percussion which had lain dormant after its invention in 1761 by Joseph Leopold Auenbrugger, and he championed its use in clinical medicine. He popularised the use of percussion with his translation in 1808 of Auenbrugger's monograph Inventum novum ex percussione thoracis humani and always gave credit to Auenbrugger for its invention.

Corvisart was a close friend of Napoleon Bonaparte, who greatly enjoyed his company. He became his personal physician and accompanied the Emperor on his campaigns. Napoleon gave him a large carved mahogany chair which he used in his consulting room.

As a young man he originally studied law, but having visited some of the hospital clinics in Paris he decided to become a physician. This so angered his father that he was expelled from the family home, but luckily he got a job at the famous Hôtel-Dieu which enabled him to study there and gain the degree of doctor-regent in $\mathbf{1 7 8 5}$.

M K DAVIES A HOLIMAN

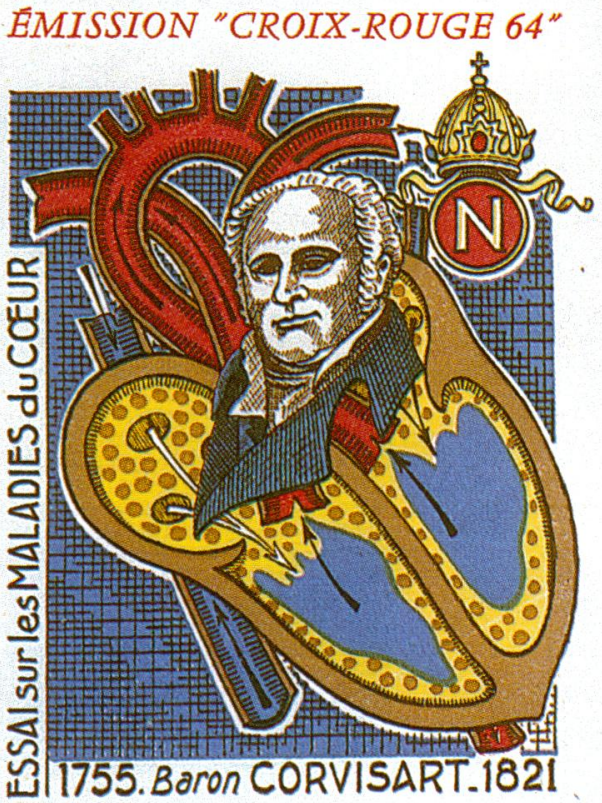

PREMIER JOUR

D.gMIS IO N

FIRST DAY COVER
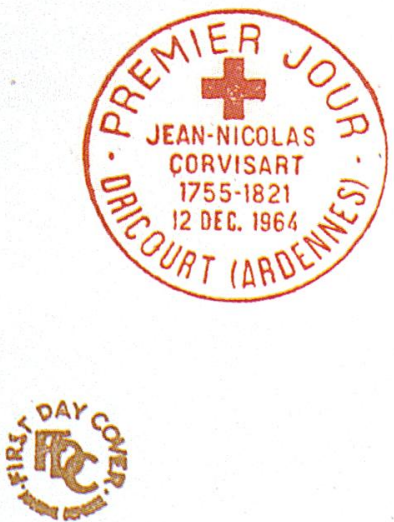